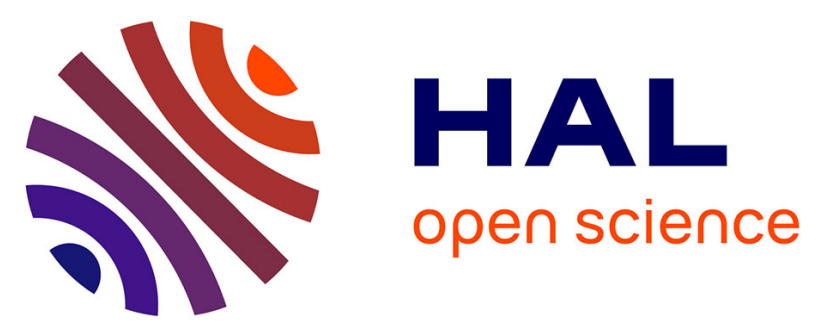

\title{
Fish-farm impact on metazoan meiofauna in the Mediterranean Sea: analysis of regional vs. habitat effects
}

Simone Mirto, Silvia Bianchelli, Cristina Gambi, Maja Krzelj, Antonio

Pusceddu, Mariaspina Scopa, Marianne Holmer, Roberto Danovaro

\section{To cite this version:}

Simone Mirto, Silvia Bianchelli, Cristina Gambi, Maja Krzelj, Antonio Pusceddu, et al.. Fish-farm impact on metazoan meiofauna in the Mediterranean Sea: analysis of regional vs. habitat effects. Marine Environmental Research, 2009, 69 (1), pp.38. 10.1016/j.marenvres.2009.07.005 . hal-00547650

\section{HAL Id: hal-00547650 \\ https://hal.science/hal-00547650}

Submitted on 17 Dec 2010

HAL is a multi-disciplinary open access archive for the deposit and dissemination of scientific research documents, whether they are published or not. The documents may come from teaching and research institutions in France or abroad, or from public or private research centers.
L'archive ouverte pluridisciplinaire HAL, est destinée au dépôt et à la diffusion de documents scientifiques de niveau recherche, publiés ou non, émanant des établissements d'enseignement et de recherche français ou étrangers, des laboratoires publics ou privés. 


\section{Accepted Manuscript}

Fish-farm impact on metazoan meiofauna in the Mediterranean Sea: analysis of regional vs. habitat effects

Simone Mirto, Silvia Bianchelli, Cristina Gambi, Maja Krzelj, Antonio

Pusceddu, Mariaspina Scopa, Marianne Holmer, Roberto Danovaro

PII:

S0141-1136(09)00104-4

DOI:

10.1016/j.marenvres.2009.07.005

Reference:

MERE 3361

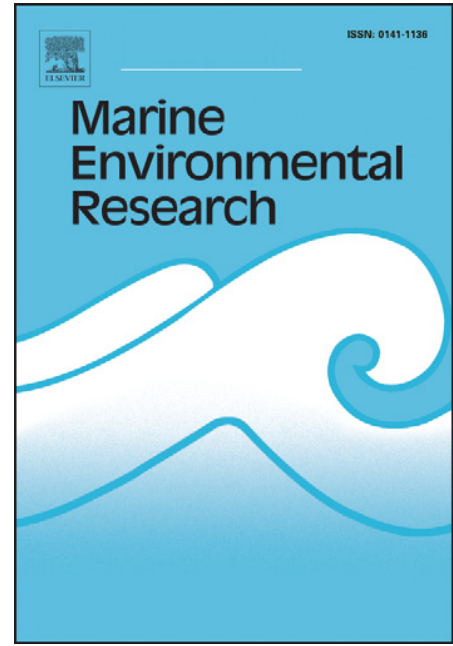

To appear in:

Marine Environmental Research

Received Date:

2 February 2009

Revised Date:

24 July 2009

Accepted Date:

28 July 2009

Please cite this article as: Mirto, S., Bianchelli, S., Gambi, C., Krzelj, M., Pusceddu, A., Scopa, M., Holmer, M., Danovaro, R., Fish-farm impact on metazoan meiofauna in the Mediterranean Sea: analysis of regional vs. habitat effects, Marine Environmental Research (2009), doi: 10.1016/j.marenvres.2009.07.005

This is a PDF file of an unedited manuscript that has been accepted for publication. As a service to our customers we are providing this early version of the manuscript. The manuscript will undergo copyediting, typesetting, and review of the resulting proof before it is published in its final form. Please note that during the production process errors may be discovered which could affect the content, and all legal disclaimers that apply to the journal pertain. 


\section{Fish-farm impact on metazoan meiofauna in the Mediterranean Sea:}

\section{2 analysis of regional vs. habitat effects}

3

4 Simone Mirto ${ }^{\mathrm{a}, \mathrm{b}}$, Silvia Bianchelli ${ }^{\mathrm{a}}$, Cristina Gambi ${ }^{\mathrm{a}}$, Maja Krzelj ${ }^{\mathrm{a}, \mathrm{c}}$ Antonio Pusceddu ${ }^{\mathrm{a}}$,

5 Mariaspina Scopa ${ }^{\mathrm{a}}$, Marianne Holmer ${ }^{\mathrm{d}}$, Roberto Danovaro ${ }^{\mathrm{a} *}$

6

$7 \quad{ }^{a}$ Department of Marine Sciences, Polytechnic University of Marche, Via Brecce Bianche, 60131 Ancona,

8 Italy

$9{ }^{b}$ Institute for the Marine Coastal Environment, National Council of Research, Spianata S. Raineri, 86 -

1098122 Messina, Italy

$11{ }^{c}$ Center of Marine Studies, University of Split, Livanjska 5/III, 21000 Split, Croatia

$12{ }^{d}$ Institute of Biology, University of Southern Denmark, Campusvej 55, DK5230, Odense M., Denmark 13

14 Submitted to

15 Marine Environmental Research

16

$17 *$ Corresponding author:

18 Prof. Roberto Danovaro

19 Dipartimento Scienze del Mare,

20 Università Politecnica delle Marche,

21 Via Brecce Bianche, 60131 Ancona, Italy

22 Tel: +390712204654

23 Fax: +390712204560

24 r.danovaro@univpm.it 


\section{ABSTRACT:}

28 The worldwide exponential growth of off-shore mariculture is raising severe concerns about the 29 impacts of this industry on marine habitats and their biodiversity. We investigated the metazoan 30 meiofaunal response to fish farm impact in four regions of the Mediterranean Sea. Meiofaunal 31 assemblages were investigated in two habitats (seagrass meadows of Posidonia oceanica and 32 non-vegetated soft bottoms) comparing sites receiving faeces and uneaten food pellets from fish 33 farms to control sites. We report here that, consistently across different regions, the meiofaunal 34 abundance typically responded positively to fish-farm effluents. Biodeposition caused also 35 significant changes in assemblage structure and the reduction in the richness of higher meiofaunal 36 taxa, but the multivariate analysis of variance revealed that the effects were region- and habitat-

37 specific. In non-vegetated systems, three of the four regions investigated displayed significant 38 effects of the fish farms on richness of meiofaunal taxa. In vegetated habitats, meiofauna did not 39 respond to biodeposition (except in one region), suggesting that seagrass meadows can mask the 40 effects of fish-farm effluents on benthic biodiversity. We conclude that different indicators of 41 fish-farm impact are needed in vegetated and non-vegetated benthic systems.

44 Key-words: fish-farm impact, meiofauna, soft sediments, Posidonia oceanica, Mediterranean

\section{Sea.}




\section{Introduction}

Eutrophication is recognized as one of the most important emerging problems of the coastal oceans and, during the past four decades, has increased exponentially in intensity, geographical area and environmental consequences (Cloern, 2001). Eutrophication is typically related to the increase of nutrient and organic matter loads, which cause a progressive decrease of dissolved oxygen concentrations (Dell'Anno et al., 2008). The accumulation of large amounts of organic matter in coastal sediments, associated with eutrophication processes, also induce significant changes in the composition of sediment organic matter, which can have putative effects on the benthos (see Pusceddu et al., 2009 for a review).

Aquaculture is a fast-growing industry which, through the release of organic and inorganic $\mathrm{N}$ and $\mathrm{P}$ contributes to the progressive eutrophication of coastal areas (see Holmer et al., 2008 and citations therein). Aquaculture activities are now relevant at local and regional scales, and recent estimates indicate that, in Mediterranean coastal areas, the release of nutrients from fish farming contributes for up to 7 and $10 \%$ of $\mathrm{N}$ and $\mathrm{P}$ total discharge, respectively (Pitta et al., 1999).

Aquaculture installations can produce relevant shifts of the whole natural environment (Boyra et al., 2004; Machias et al., 2004), threatening the environmental quality of coastal zones (Gowen and Bradbury, 1987) and generating conflicts between aquaculture and the conservation of marine habitats, including the protection of large benthic primary producers, such as the seagrass Posidonia oceanica.

The organic enrichment of the sediments immediately beneath the sea cages is a direct result of the sedimentation of particulate waste products from the fish farm (Hargrave et al., 1997; Karakassis et al., 1998; Holmer et al., 2008) and a decreasing concentration with the increasing distance from the point source is typically observed (Hargrave et al., 1993; Mazzola 
71 et al., 1999; Pusceddu et al., 2007; Holmer et al., 2007). The continuous flow of faeces and 72 food pellets from fish cages alters the quantity and the biochemical composition of sediment 73 organic matter, but with potentially different effects in different regions and/or habitats. In fact, previous studies, carried out in non-vegetated and seagrass habitats of four

75 Mediterranean regions (Cyrus, Greece, Italy and Spain), have shown that the response of the 76 benthic biochemistry to aquaculture biodeposition is idiosyncratic, and significant increase in 77 the organic load can be detected only in those regions characterized by biopolymeric $\mathrm{C}$ contents 78 typically, $2 \mathrm{mg} \mathrm{C} \mathrm{g}^{-1}$ (Pusceddu et al., 2007).

80 investigated meiofaunal assemblages in different regions of the Mediterranean Sea along a

81 longitudinal gradient of trophic conditions (in terms of primary productivity, Pusceddu et al., 82 2007). Metazoan meiofauna, for their ecological importance in the benthic ecosystems and the 83 lack of larval dispersion, are considered a sensitive tool for investigating structural and functional 84 changes of natural and anthropogenically-impacted ecosystems (see Vincx and Heip, 1987 for a 85 review).

86 Here we tested, using a hierarchical sampling strategy under uni- and multi-variate contexts, the hypothesis that the presence of fish farms influences significantly the meiofaunal 88 assemblages in terms of abundance, community structure and diversity (i.e. richness and 89 evenness of taxa) and that different patterns can be expected in the four regions according to their 90 different trophic backgrounds. 


\section{Materials and Methods}

\subsection{Study site and sampling strategy}

To cover different environmental conditions characterizing Mediterranean coastal zones along an east-to-west longitudinal transect (ca. 3,500 km wide), four regions were selected: Akrotiri Bay

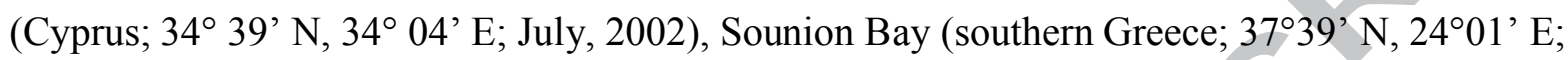
July, 2003), Pachino Bay (Italy; 36² $43^{\prime}$ N, $15^{\circ} 05^{\prime} \mathrm{E}$; September, 2002), and Gulf of Alicante (Spain; 38 24' N, 0²4' W; September, 2003) (Figure 1). All of these regions, located at similar latitudes and depths were selected on the basis of the presence of the fish farms, which have been previously characterized in terms of their main environmental features (Table 1). In each of the sampling regions, the effects of the fish farm on the meiofauna were investigated in two different habitats: meadows of the seagrass Posidonia oceanica, and soft non- vegetated bottoms. In each region, a preliminary survey was carried out to ascertain the presence of both the seagrass and the soft substrates, and to characterize the environmental settings of the areas in terms of mean depth and temperature, bottom currents, sediment type and porosity, and chlorophyll-a and inorganic nutrient concentrations in the water column (Karakassis et al., 2005). In each habitat, the impact was quantified by contrasting the fish-farm sites with control sites characterized by relatively pristine conditions and by environmental features comparable to those found beneath the cages (Table 1). Controls were located upstream of the main currents, and at least 1,000 $\mathrm{m}$ from the fish farms. It has been demonstrated that this distance avoids any potential effect of fish farms (Holmer et al., 2008) and allows maintaining the spatial variability in background (control) conditions as low as possible.

At each site, three replicates were collected randomly from the central area of each fishfarm site (i.e. beneath the cages) and in each control site, by means of manual corers (diameter $3.7 \mathrm{~cm}, 10.7 \mathrm{~cm}^{2}$ surface area, down to a depth of $10 \mathrm{~cm}$ ) operated by SCUBA divers. 


\subsection{Sediment biochemistry}

Sediment protein, carbohydrate and lipid contents were determined spectrophotometrically and concentrations were converted into carbon equivalents using 0.40 and 0.49 and $0.75 \mathrm{~g} \mathrm{C} \mathrm{g}^{-1}$ conversion factors, respectively, and their sum reported as biopolymeric C (Pusceddu et al., 2009). Data relative to the quantity and biochemical composition (i.e. protein, carbohydrate and lipid contents) of organic matter in the sediments under scrutiny have been detailed elsewhere (Pusceddu et al., 2007). In this study, we focused our attention on the biopolymeric C concentrations and on the values of the protein to carbohydrate ratio as descriptors of the quantity and quality of sediment organic matter, respectively (Pusceddu et al., 2009).

\subsection{Meiofaunal analyses}

Each sediment sample was fixed with $4 \%$ buffered formaldehyde (in filtered seawater solution) and was sieved through $1000 \mu \mathrm{m}$ sieve (to retain macrobenthos and macroalgae) and $32 \mu \mathrm{m}$ sieve (to retain smaller meiofauna) in laboratory. The sample fraction retained by a $32 \mu \mathrm{m}$ mesh net was added to Ludox HS 40 (density arranged to $1.18 \mathrm{~g} \mathrm{~cm}^{-3}$ ), for density centrifugation extraction (10 min, $800 \times \mathrm{g}$, for 3 times) from the sediment (Heip et al., 1985). All metazoan animals were counted and classified per taxon under a stereomicroscope using Delfuss cuvettes, after staining 134 with Rose Bengal $\left(0.5 \mathrm{~g} \mathrm{~L}^{-1}\right)$. Community evenness was calculated as the Pielou's index using the different meiofaunal taxa as entries, by means of the PRIMER software (Clarke and Gorley, 2003).

\section{$38 \quad 2.4$ Statistical analyses}

139 Differences between control and impact sediments were assessed for all of the investigated variables using a three-way analysis of variance (ANOVA). The analysis treated the factor region 
( $\mathrm{R}, 4$ levels) as random, habitat (H, 2 levels) as fixed and crossed with R, and impact (I, 2 levels)

as fixed and orthogonal to $\mathrm{R}$ and $\mathrm{H}$. When significant differences $(\mathrm{p}<0.05)$ were observed, a posthoc Student-Newman-Kuels' test (SNK) was also performed. ANOVA and SNK tests were carried out using the GMAV software (University of Sidney).

Distance-based permutational multivariate analyses of variance (PERMANOVA, Anderson, 2001) were used to quantify in the two benthic habitats the effects of the fish farms on i) the organic matter quantity and quality and ii) the meiofaunal assemblages. The analysis treated the factor region (R, 4 levels) as random, habitat (H, 2 levels) as fixed and crossed with $\mathrm{R}$, and impact (I, 2 levels) as fixed and orthogonal to R and H. For organic matter, the data set included 48 observations on concentrations of biopolymeric $\mathrm{C}$ and the values of the protein to carbohydrate ratio. For meiofauna, the data set included 48 observations and the abundance of all the taxa. Since the interaction term $\mathrm{R} \times \mathrm{H} \times \mathrm{I}$ was seen to be significant either for organic matter and meiofauna, pairwise comparisons, which also used 499 random permutations to obtain Pvalues, were also carried out to ascertain differences between control and impact sediments in all regions, separately. The P-values were calculated using 499 Monte Carlo draws from the asymptotic permutation distribution (Anderson and Robinson, 2003). PERMANOVA tests were carried out (either in the uni- and multivariate contexts) also removing the effects of the main environmental variables (i.e., water depth, current speed, sediment type, porosity and water content, biopolymeric $\mathrm{C}$ and protein to carbohydrate ratio) as covariates.

In order to assess whether and how much environmental variables explained changes in meiofaunal abundance, richness and evenness of taxa, a non-parametric multivariate multiple regression analysis that was based on Euclidean distances was carried out using the routine DISTLM forward (Mc Ardle and Anderson, 2001). The forward selection of the predictor variables was carried out with tests by permutation. P values were obtained using 4,999 
permutations of raw data for the marginal tests (tests of individual variables), while for all of the conditional tests, the routine uses 4,999 permutations of residuals under a reduced model.

\section{Results}

Three-way univariate ANOVA revealed that biopolymeric $\mathrm{C}$ concentrations and values of the protein to carbohydrate ratio displayed a significant Region $(\mathrm{R}) \times$ Habitat $(\mathrm{H}) \times \operatorname{Impact}(\mathrm{I})$ effect (Table 2), with differences between impacted and control sites varying between the two habitats and the four geographical areas. In particular, the SNK tests revealed that biopolymeric C concentrations in farm-impacted sediments increased consistently in vegetated sediments in Cyprus, in both habitats in Greece and in non-vegetated sediments in Italy (Figure 2A), whereas values of the protein to carbohydrate ratio increased in impact sites in non-vegetated sediments in Cyprus, in both habitats in Italy and in non-vegetated sediments in Spain and decreased in impact sediments of both habitats in Greece (Figure 2B).

A general increase of meiofaunal abundance was observed in impacted sediments (Figure $3 \mathrm{~A}$ ) and the ANOVA revealed significant $\mathrm{R} \times \mathrm{H} \times \mathrm{I}$ variations in total meiofaunal abundance (Table 3). Moreover, the SNK tests indicated that total meiofaunal abundance increased significantly in impact sites in vegetated sediments in Cyprus and non-vegetated sediments in Italy, whereas no significant differences between impact and control sediments were observed in all other regions and habitats (Figure 3A).

Abundance of all of the meiofaunal taxa in the sediments are reported in Table 4 . ANOVA revealed significant $\mathrm{R} \times \mathrm{H} \times \mathrm{I}$ effects on the abundance of all of the meiofaunal taxa with differences between impact and control sites differing in extent and direction in different regions and habitats and for the different taxa (Table 5). Significant interaction of the $\mathrm{R} \times \mathrm{H} \times \mathrm{I}$ factors, indicating idiosyncratic responses to fish-farm impact in different regions and habitats, 
was observed for polychaetes, gastrotrichs, bivalves, cumaceans and tanaidaceans. The SNK tests (data not shown) revealed increasing nematode abundance beneath the cages in vegetated sediments in Cyprus and in both habitats in Greece. Copepods increased in both fish-impacted habitats in Cyprus. The abundance of ostracods varied between impacted and control sites only in Spain (in both habitats), whereas oligochaetes, kinorhynchs and amphipods did not display any significant difference between impact and control sediments in any of the investigated region and habitat. Turbellarians' abundance exhibited significant differences only between regions.

The PERMANOVA test applied on the meiofaunal community composition showed a significant $\mathrm{R} \times \mathrm{H} \times \mathrm{I}$ effect, indicating that the differences between control and fish-farm impacted sites varied between the two habitats and the four regions (Table 6, Figure 3B-C). The analysis carried out separately for all of the four regions and the pairwise comparison tests revealed that differences between impact and control sites in the meiofaunal community composition were significant only in non-vegetated sediments either in Cyprus and Greece. At all sites nematodes and copepods were the most dominant taxa, followed by polychaetes, ostracods, turbellarians, oligochaetes, gastrotrichs and all other taxa.

The richness of meiofaunal taxa decreased significantly in impacted sites in all non-vegetated sediments, whereas no significant differences between impact and control sites were observed in seagrass sediments (Table 7 and Figure 4A). On the other hand, significant differences in community evenness were observed between regions and between impact and control sites only in non-vegetated sediments in Cyprus (Table 7, Figure 4B). 


\section{Discussion}

\subsection{Impacts of fish-farm effluents on meiofaunal abundance}

Ecosystem alterations induced by different typologies of disturbance, including human impacts, generate variable shifts in benthic species, assemblages and community composition. Fish farming, by modifying the whole attributes of the benthic environment beneath the cages, produces relevant modifications in the abundance, biomass, species composition and evenness of meio- and macrofauna (e.g. Mirto et al., 2002; Kalantzi and Karakassis, 2006).

The responses of metazoan meiofauna to various ecosystem alterations are clearly detected at the highest taxonomic level, with a resolution similar to that provided by the analysis of lower taxonomic levels (Kennedy and Jacoby, 1999; Warwick 1988), also under the influence of fish farms (Sutherland et al. 2007).

In this study, we analysed the potential effects of fish farm effluents on the abundance and community composition of meiofauna, by comparing, for the first time, two different habitats in four different regions with different background trophic conditions. The general outcome from the available literature is that fish-farm effluents typically alter meiofaunal abundance, diversity, biomass, and species composition (Duplisea and Hargrave, 1996; Kennedy and Jacoby, 1999; Mirto et al., 2000; -2002; La Rosa et al., 2001; Sutherland et al., 2007). However, changes associated with the presence of fish-farm effluents are often not consistent, as meiofaunal abundance may either increase or decrease beneath the fish cages, depending on the site or the farm characteristics.

In the present study, the idiosyncratic meiofaunal responses to fish farm impact was confirmed. Although total meiofaunal abundance was generally higher in the fish-farm than in the control sediments, such changes were not always statistically significant. This result is apparently in contrast to previous investigations reporting a decrease of meiofaunal abundance in 
non-vegetated systems subjected to bio-deposition from fish cages (Mirto et al., 2002; Sutherland et al., 2007). The general positive response of meiofaunal abundance to fish-farm biodeposition could be related to the relatively limited organic enrichment in the sediments beneath the cages, as reported in sediments subjected to mussel farm bio-deposition, where the organic inputs to the bottom were similarly low (Danovaro et al., 2004).

The results of the PERMANOVA, carried out in the univariate context, revealed that differences in total meiofaunal abundance between impact and control sites were due to the effects of the environmental covariates (Table 8). The effect of organic matter enrichment in fishfarm sediments was significant only in oligotrophic regions (i.e., Cyprus and Greece). The multiple regression analysis, indeed, revealed that, among the different environmental variables, only the current speed and the biopolymeric $\mathrm{C}$ concentrations explained significant proportions ( $15 \%$ and $9 \%$, respectively) of the total meiofaunal abundance (Table 9). This result supports the expectation that changes in meiofaunal abundance in fish-farm sediments are linked to the organic matter inputs released by the fish farm, as well as to the local hydrodynamism.

The results of this study suggest that the impact of aquaculture effluents on the meiofaunal abundance is both region- and habitat-specific and also highlight that the direction and intensity of the response of total meiofaunal abundance to aquaculture effluents depend on the environmental conditions.

\subsection{Impacts of fish-farm effluents on meiofaunal communities}

The results presented here provide evidence that, in all investigated regions, consistent significant effects of fish-farming effluents on meiofaunal biodiversity can only be detected in non-vegetated sediments. In all soft bottoms beneath fish farms the richness of higher taxa decreased significantly when compared to control sites (from 13-16 in all control sediments to a 
minimum of 9 taxa in non-vegetated impact sediments in Spain), whereas no significant differences were observed in terms of taxa evenness. The taxa that disappeared beneath the cages changed amongst regions, but always included the rare taxa (i.e., taxa representing $<1 \%$ of the total meiofaunal abundance; Figure 3C) of the control sites. Meiofaunal taxa disappeared in fishfarm sediments included kinorhynchs (only in non-vegetated sediments in Spain), cumaceans (in $37.5 \%$ of the total cases, i.e., in non-vegetated sediments in Cyprus, Italy and Spain), isopods (37.5\%, in non vegetated sediments in Cyprus and Greece and in vegetated sediments in Spain), thanaidaceans (37.5\% in non-vegetated sediments in Cyprus and both habitats in Greece), amphipods (50\%, in non-vegetated sediments in Greece, Italy and Spain and in vegetated sediments in Italy), and tardigrades ( $25 \%$ of the total cases: in non-vegetated sediments in Cyprus and Spain). These results do not allow identifying specific taxa as indicators of biodeposition impact.

The analysis of meiofaunal assemblage attributes (meiofaunal abundance, community composition, richness of taxa and community evenness) within seagrass sediments revealed that all of these variables responded idiosyncratically to the presence of fish farming activities. The lack of a clear and consistent meiofaunal response to the fish-farm biodeposition in seagrass sediments could have several possible explanations. Posidonia oceanica is a seagrass endemic of the Mediterranean Sea, which covering ca $50.000 \mathrm{~km}^{2}$, plays a key ecological role for a wide range of organisms and assemblages, preserving their biodiversity and protecting the integrity of the coastal areas (Hemminga and Duarte, 2000). The effects of fish-farm biodeposition on seagrass meadows can be difficult to detect due to the fact that the presence of the seagrass masks the changes in organic matter concentrations and composition (Pusceddu et al., 2007). However, the presence of a large number of filter feeders and detritus feeders associated with the seagrass bed can also act as a buffer for the organic enrichment, by consuming a large fraction of the 
biodeposits (Balata et al., 2008). Moreover, the presence of a large assemblage of prokaryotes, protozoa and meiofauna within the seagrass sediments makes it difficult to detect the presence of significant changes in these components (Danovaro 1996, Bongiorni et al., 2005). Posidonia oceanica is known to be highly sensitive to anthropogenic impacts, and it has been demonstrated that, in the long term (i.e. years to decades), the increased sedimentation of waste particles and the accumulation of organic matter lead to the deterioration of the seagrass system (PergentMartini et al., 2006). In the regions investigated, the seagrass systems displayed a clear impact and several indicators of deterioration of the Posidonia meadows were reported (Holmer et al., 2008). However, the effects of biodeposition on meiofaunal variables were not evident, indicating that in seagrass systems the search for meiofaunal indicators of impact is unnecessary as it provides, if any, a slow or late response to the fish-farm impact.

\subsection{Conclusions and perspectives}

In this study we showed that fish-farm biodeposition in the Mediterranean Sea can provoke changes in meiofaunal abundance, community structure and the biodiversity at high taxonomic levels. However, the hierarchical sampling conducted here demonstrated that the meiofaunal responses varied among regions and habitats. In all non-vegetated sediments the richness of meiofaunal taxa decreased in response to fish-farm biodeposition, and therefore independently from the background environmental conditions. Conversely, in seagrass sediments, the idiosyncratic response did not allow any clear indicator of impacts from fishfarm bio-deposition to be identified. The results of this study highlight the importance of using 303 different indicators of fish-farm impact in vegetated and non-vegetated systems. 


\section{Acknowledgements}

The authors thank the EU project MedVeg ( ${ }^{\circ}$ EU Quality of Life \& Management of Living Resources Programme, Contract No. Q5RS-2001-02456.).

\section{References}

Anderson, M.J., 2001. A new method for non-parametric multivariate analysis of variance. Austral Ecology 26, 32-46.

Anderson, M.J., Robinson, R., 2003. Generalised discriminant analysis based on distances. Australian and New Zealand Journal of Statistics 45, 301-318.

Balata, D., Bertocci, I., Piazzi, L., Nesti, U. 2008. Comparison between epiphyte assemblages of leaves and rhizomes of the seagrass Posidonia oceanica subjected to different levels of anthropogenic eutrophication. Estuarine Coastal and Shelf Science 79, 533-540.

Bongiorni, L., Mirto, S., Pusceddu, A., Danovaro, R., 2005. Response of benthic protozoa and thraustochytrid protists to fish farm impact in seagrass (Posidonia oceanica) and soft-bottom sediments. Microbial Ecology 50, 268-276.

Boyra, A., Sanchez-Jerez, P., Tuya, F., Espino, F., Haroun R. 2004. Attraction of wild coastal fishes to an Atlantic subtropical cage fish farms, Gran Canaria, Canary Islands.

Environmental Biology of Fishes 70, 393-401.

Clarke, K.R., Gorley, R.N., 2003. PRIMER 5 (Plymouth Routines in Multivariate Ecological Research). Plymouth Marine Laboratory, Plymouth, United Kingdom.

Cloern, J.E., 2001. Our evolving conceptual model of the coastal eutrophication problem. Marine Ecology Progress Series 210, 223-253.

Danovaro, R., 1996. Detritus-Bacteria-Meiofauna Interactions in a seagrass bed (Posidonia oceanica) of the NW Mediterranean. Marine Biology 127, 1-13. 
Danovaro, R., Gambi, C., Luna, G.M., Mirto, S., 2004. Sustainable impact of mussel farming in the Adriatic Sea (Mediterranean Sea): evidence from biochemical, microbial and meiofaunal indicators. Marine Pollution Bulletin 49, 325-333.

Dell'Anno, A., Pusceddu, A., Langone, L., Danovaro, R. 2008. Early diagenesis of organic matter in coastal sediments influenced by riverine inputs. Chemistry and Ecology 24, 75-85.

Duplisea, D.E., Hargrave, B.T., 1996. Response of meiobenthic size-structure, biomass and respiration to sediment organic enrichment. Hydrobiologia 339, 161-170.

Gowen, R.J., Bradbury, N.B., 1987. The ecological impact of salmonid farming in coastal waters: a review. Oceanography and Marine Biology: An Annual Review 25, 563- 575.

Hargrave, B.T., Duplisea, D.E., Pfeifer, E., Wildish, D.J., 1993. Seasonal changes in benthic fluxes of dissolved oxygen and ammonium associated with marine cultured Atlantic salmon. Marine Ecology Progress Series 96, 249-257.

Hargrave, B.T., Phillips, G.A., Doucette, L.I., White, M.J., Milligan, T.G., Wildish, D.J., Cranston, R.E., 1997. Assessing benthic impacts of organic enrichment from marine aquaculture. Water Air and Soil Pollution 99, 641-650.

Heip, C., Vincx, M., Vranken, G. 1985. The ecology of marine nematodes. Oceanography Marine Biology Annual Review 23, 399-489.

Hemminga, M.A., Duarte, C.M., 2000. Seagrass Ecology, Cambridge University Press, Cambridge.

Holmer, M., Marbà, N., Diaz-Almela, E., Duarte, C.M., Tsapakis, M., Danovaro, R., 2007. Sedimentation of organic matter from fish farms in oligotrophic Mediterranean assessed through bulk and stable isotope $\left(\delta^{13} \mathrm{C}\right.$ and $\left.\delta^{15} \mathrm{~N}\right)$ Aquaculture 262, 268-280.

Holmer, M., Frederiksen, M., Pusceddu, A., Danovaro, R., Mirto, S., Perez, M., Marbà, N., Duarte, C.M., Diaz-Almela, E., Tsapakis, M., Karakassis, Y., 2008. Effects of fish-farm 
waste on Posidonia oceanica meadows: synthesis and provision of management tools. Marine Pollution Bulletin 56, 1618-1629.

Kalantzi, I., Karakassis, I., 2006. Benthic impacts of fish farming: Meta-analysis of community and geochemical data. Marine Pollution Bulletin 52, 484-493.

Karakassis, I., Tsapakis, M., Hatziyanni, E., 1998. Seasonal variability in sediments profiles beneath fish farm cages in the Mediterranean. Marine Ecology Progress Series 162, 243-252.

Karakassis, I., Pitta, P., Krom, M.D., 2005. Contribution of fish farming to the nutrient loading of the Mediterranean. Scientia Marina 69, 313-321.

Kennedy, A.D., Jacoby, C.A., 1999. Biological indicators of marine environmental health: meiofauna - a neglected benthic component? Environmental Monitoring Assessment 54, 4768.

La Rosa, T., Mirto, S., Mazzola, A., Danovaro, R., 2001. Differential responses of benthic microbes and meiofauna to fish-farm disturbance in coastal sediments. Environmental Pollution 112, 427-434.

Machias, A., Karakassis, I., Labropoulou M., Somarakis, S., Papadopoulou K.N., Papaconstantinou C., 2004. Changes in wild fish assemblages after the establishment of a fish farming zone in an oligotrophic marine ecosystem. Estuarine Coastal and Shelf Science 60, 771-779.

Mazzola, A., Mirto, S., Danovaro, R., 1999. Initial fish-farm impact on meiofaunal assemblages in coastal sediments of the Western Mediterranean. Marine Pollution Bulletin 38, 11261133.

McArdle, B.H., Anderson, M.J., 2001. Fitting multivariate models to community data: A comment on distance-based redundancy analysis. Ecology 82, 290-297.

Mirto, S., La Rosa, T., Danovaro, R., Mazzola, A., 2000. Microbial and meiofaunal response to 
intensive mussel-farm biodeposition in coastal sediments of the Western Mediterranean. Marine Pollution Bulletin 40, 244-252.

Mirto, S., La Rosa, T., Gambi, C., Danovaro, R., Mazzola, A., 2002. Nematode community response to fish-farm impact in the western Mediterranean. Environmental Pollution 116, 203-214.

Pergent-Martini, C., Boudouresque, C.-F., Pasqualini, V., Pergent, G. 2006. Impact of fish farming facilities on Posidonia oceanica meadows: a review. Marine Ecology an Evolutionary Perspective 27, 310-319.

Pitta, P., Karakassis, I., Tsapakis, M., Zivanovic, S., 1999. Natural vs. mariculture induced variability in nutrients and plankton in Eastern Mediterranean. Hydrobiologia 391, 181-194.

Pusceddu, A., Fraschetti, S., Mirto, S., Holmer, M., Danovaro, R., 2007. Effects of intensive mariculture on sediment biochemistry. Ecological Applications 17, 1366-1378.

Pusceddu, A., Dell'Anno, A. Fabiano, M., Danovaro, R., 2009. Quantity and bioavailability of sediment organic matter as signatures of benthic trophic status. Marine Ecology Progress Series $375,41-52$.

Sutherland, T.F., Levings, C.D., Petersen, S.A., Poon, P., Piercey, B., 2007. The use of meiofauna as an indicator of benthic organic enrichment associated with salmonid aquaculture. Marine Pollution Bulletin 54, 1249-1261.

Vincx, M., Heip, C., 1987. The use of meiofauna in pollution monitoring studies. A review. ICES Journal of Marine Science 16, 50-67.

Warwick, R. M.. 1988. The level of taxonomic discrimination required to detect pollution effects on marine benthic communities. Marine Pollution Bulletin19, 259-268. 


\section{Figure Captions}

Figure 1. Sites of the four fish-farms investigated in Cyprus, Italy, Greece and Spain in the Mediterranean Sea.

Figure 2. Biopolymeric C concentrations (A) and values of the protein to carbohydrate ratio (B) in the investigated sediments. According to the SNK tests (at $\mathrm{p}<0.05),+=$ increase; - = decrease; $n s=$ not significant. Data are extracted from Pusceddu et al. (2007).

Figure 3. Total meiofaunal abundance (A), meiofaunal community composition (B) and the relative abundance of rare taxa (C) in Cyprus, Greece, Italy and Spain in non-vegetated and vegetated habitats, in control (C) and impact (I) sediments.

Figure 4. Taxa richness (A) and community evenness (B) in Cyprus, Greece, Italy and Spain in non-vegetated and vegetated habitats, in control (C) and impact (I) sediments. The statistical significance of the differences among bars (SNK test: $+=$ increase $p<0.05,-=$ decrease $\mathrm{p}<0.05, \mathrm{~ns}=$ not significant) are also reported. 
1 Table 1 - Environmental characteristics reported in all sampling sites (distance of the sampling sites from the fish farm, water depth,

2 current speed, sediment type, porosity, water content and grain size).

3

\begin{tabular}{|c|c|c|c|c|c|c|c|c|c|}
\hline Region & Habitat & Site & $\begin{array}{l}\text { Distance from } \\
\text { fish farm (m) }\end{array}$ & $\begin{array}{l}\text { Water Depth } \\
\text { (m) }\end{array}$ & $\begin{array}{l}\text { Current speed } \\
\left.\text { (cm sec }{ }^{-1}\right)\end{array}$ & $\begin{array}{l}\text { Sediment type } \\
\text { Silt/Clay (\%) }\end{array}$ & $\begin{array}{c}\text { Sediment } \\
\text { Porosity (\%) }\end{array}$ & $\begin{array}{c}\text { Sediment Water } \\
\text { Content (\%) }\end{array}$ & $\begin{array}{c}\text { Grain Size } \\
\text { (Mean Diameter, mm) }\end{array}$ \\
\hline \multirow{4}{*}{ Cyprus } & non- & Impact & $0-20$ & 30 & $20-40$ & 80.7 & 1.2 & 42.9 & 0.01 \\
\hline & vegetated & Control & 4000 westward & 30 & $20-40$ & 75.9 & 1.2 & 44.9 & 0.02 \\
\hline & \multirow{2}{*}{ Vegetated } & Impact & 300 northward & 20 & $20-40$ & 68.4 & 1.2 & 46.4 & 0.02 \\
\hline & & Control & 1000 eastward & 20 & $20-40$ & 2.5 & 1.1 & 36.5 & 0.10 \\
\hline \multirow{4}{*}{ Italy } & non- & Impact & 0 & 22 & 20 & 5.7 & 1.2 & 41.6 & 0.47 \\
\hline & vegetated & Control & 3200 north-east & 22 & 20 & 3.9 & 0.8 & 13.5 & 0.84 \\
\hline & \multirow{2}{*}{ Vegetated } & Impact & 5 & 22 & 20 & 4.6 & 1.2 & 46.9 & 0.45 \\
\hline & & Control & 1000 northward & 22 & 20 & 4.8 & 1.1 & 33.7 & 0.90 \\
\hline \multirow{4}{*}{ Greece } & non- & Impact & 0 & 16 & 6.3 & 6.7 & 1.1 & 29.5 & 0.38 \\
\hline & vegetated & Control & 800 westward & 16 & 6.3 & 2.2 & 1.6 & 18 & 1.89 \\
\hline & \multirow{2}{*}{ Vegetated } & Impact & 5 & 16 & 6.3 & 20.2 & 1.0 & 27.3 & 0.33 \\
\hline & & Control & 1000 southward & 15 & 6.3 & 13.1 & 1.1 & 34.4 & 0.76 \\
\hline \multirow{4}{*}{ Spain } & non- & Impact & 0 & 29 & 4.7 & 7.7 & 1.1 & 31.7 & 0.32 \\
\hline & vegetated & Control & 1000 westward & 29 & 4.7 & 15.6 & 1.2 & 42.3 & 0.43 \\
\hline & \multirow{2}{*}{ Vegetated } & Impact & 10 & 29 & 4.7 & 16.2 & 1.1 & 32.5 & 0.40 \\
\hline & & Control & 1000 southward & & 4.7 & 15.3 & 1.1 & 32.4 & $0, .9$ \\
\hline
\end{tabular}

4 
5 Table 2 - Results of ANOVA testing for differences between impact and control sites in quantity 6 and quality of sediment organic matter in different habitats and regions. $\mathrm{R}=$ region; $\mathrm{H}=$ habitat; $\mathrm{I}$ 7 impact; $\mathrm{SS}=$ sum of squares; $\mathrm{DF}=$ degrees of freedom; $\mathrm{MS}=$ means square; $\mathrm{F}=\mathrm{F}$ value; $\mathrm{P}=$ 8 probability level: $* * *=\mathrm{P}<0.001$; $\mathrm{ns}=$ not significant.

9

\begin{tabular}{llccccc} 
& Source & SS & DF & MS & F & P \\
\hline Biopolymeric C & $\mathbf{R}$ & 38.74 & 3 & 12.91 & 28.63 & $* * *$ \\
& $\mathbf{H}$ & 3.54 & 1 & 3.54 & 0.73 & $\mathrm{~ns}$ \\
& $\mathbf{I}$ & 4.40 & 1 & 4.39 & 0.53 & $\mathrm{~ns}$ \\
& $\mathbf{R} \times \mathbf{H}$ & 14.53 & 3 & 4.84 & 10.74 & $* * *$ \\
& $\mathbf{R} \times \mathbf{I}$ & 25.01 & 3 & 8.34 & 18.48 & $* * *$ \\
& $\mathbf{H} \times \mathbf{I}$ & 3.99 & 1 & 3.99 & 1.00 & $\mathrm{~ns}$ \\
Protein to & $\mathbf{R} \times \mathbf{H} \times \mathbf{I}$ & 11.99 & 3 & 3.99 & 8.86 & $* * *$ \\
carbohydrate rations & $\mathbf{R e s i d u a l s}$ & 14.43 & 32 & 0.45 & & \\
& Total & 116.64 & 47 & & & \\
& $\mathbf{R}$ & & & & & \\
& $\mathbf{H}$ & 12.83 & 3 & 4.28 & 285.87 & $* * *$ \\
& $\mathbf{I}$ & 0.05 & 1 & 1.72 & 2.65 & $\mathrm{~ns}$ \\
& $\mathbf{R} \times \mathbf{H}$ & 1.95 & 3 & 0.05 & 0.01 & $\mathrm{~ns}$ \\
& $\mathbf{R} \times \mathbf{I}$ & 10.66 & 3 & 3.55 & 237.45 & $* * *$ \\
& $\mathbf{H} \times \mathbf{I}$ & 1.23 & 1 & 1.23 & 5.12 & $\mathrm{~ns}$ \\
& $\mathbf{R} \times \mathbf{H} \times \mathbf{I}$ & 0.72 & 3 & 0.24 & 16.04 & $* * *$
\end{tabular}

10

11 
12 Table 3 - Results of ANOVA testing for differences between impact and control sites in total

13 meiofaunal abundance in different habitats and regions. $\mathrm{R}=$ region; $\mathrm{H}=$ habitat; $\mathrm{I}=$ impact; $\mathrm{SS}=$

14 sum of squares; $\mathrm{DF}=$ degrees of freedom; $\mathrm{MS}=$ means square; $\mathrm{F}=\mathrm{F}$ value; $\mathrm{P}=$ probability level:

$15 * * *=\mathrm{P}<0.001 ; \mathrm{ns}=$ not significant.

16

17

$\begin{array}{lccccc}\text { Source } & \text { DF } & \text { SS } & \text { MS } & \mathbf{F} & \mathbf{P} \\ \mathbf{R} & 3 & 27255106 & 9085035 & 11.7511 & * * \\ \mathbf{H} & 1 & 909986 & 909986 & 0.2431 & \mathrm{~ns} \\ \mathbf{I} & 1 & 13917504 & 13917504 & 4.4563 & \mathrm{~ns} \\ \mathbf{R} \times \mathbf{H} & 3 & 11228668 & 3742889 & 4.8413 & * * \\ \mathbf{R} \times \mathbf{I} & 3 & 9369245 & 3123082 & 4.0396 & * \\ \mathbf{H} \times \mathbf{I} & 1 & 347142.6 & 347142.6 & 0.1521 & \mathrm{~ns} \\ \mathbf{R} \times \mathbf{H} \times \mathbf{I} & 3 & 6848726 & 2282909 & 2.9528 & * \\ \mathbf{R} \text { esiduals } & 32 & 24739857 & 773120.5 & & \\ \text { Total } & 47 & 94616234 & & & \end{array}$

18

19 
20 Table 4 - Meiofaunal taxa abundance (ind $10 \mathrm{~cm}^{-2}$ ) in fish-farm impacted and control sites across 21 the four regions and the two habitats. Reported are average value \pm standard deviation.

Site Location $\quad$ Site $\quad$ Nematoda Copepoda Polychaeta Ostracoda Turbellaria Oligochaeta Gastrotricha Bivalvia

\begin{tabular}{|c|c|c|c|c|c|c|c|c|c|c|}
\hline \multirow[t]{4}{*}{ Cyprus } & Non-vegetated & Control & $1903 \pm 499$ & $192 \pm 43$ & $64 \pm 14$ & $3 \pm 0$ & $9 \pm 8$ & $9 \pm 6$ & $2 \pm 0$ & $1 \pm 0$ \\
\hline & & Impact & $1751 \pm 365$ & $438 \pm 56$ & $69 \pm 5$ & $0 \pm 0$ & $4 \pm 2$ & $53 \pm 20$ & $20 \pm 17$ & $1 \pm 0$ \\
\hline & Vegetated & Control & $898 \pm 157$ & $186 \pm 26$ & $52 \pm 0$ & $3 \pm 2$ & $1 \pm 1$ & $8 \pm 6$ & $2 \pm 2$ & $2 \pm 0$ \\
\hline & & Impact & $1919 \pm 145$ & $312 \pm 65$ & $90 \pm 2$ & $5 \pm 2$ & $2 \pm 2$ & $7 \pm 7$ & & $1 \pm 0$ \\
\hline \multirow[t]{4}{*}{ Greece } & Non-vegetated & Control & $813 \pm 248$ & $595 \pm 253$ & $37 \pm 13$ & $27 \pm 17$ & $16 \pm 3$ & $20 \pm 6$ & $61 \pm 4$ & $1 \pm 1$ \\
\hline & & Impact & $3406 \pm 1798$ & $757 \pm 147$ & $549 \pm 217$ & $45 \pm 47$ & $23 \pm 6$ & $155 \pm 73$ & $344 \pm 26$ & $1 \pm 1$ \\
\hline & Vegetated & Control & $583 \pm 262$ & $582 \pm 258$ & $87 \pm 53$ & $15 \pm 5$ & $7 \pm 2$ & $13 \pm 12$ & $43 \pm 8$ & $86 \pm 40$ \\
\hline & & Impact & $1218 \pm 201$ & $784 \pm 809$ & $87 \pm 103$ & $19 \pm 27$ & $18 \pm 6$ & $35 \pm 16$ & $224 \pm 80$ & $0 \pm 0$ \\
\hline \multirow[t]{4}{*}{ Italy } & Non-vegetated & Control & $367 \pm 69$ & $409 \pm 48$ & $52 \pm 18$ & $14 \pm 3$ & $1 \pm 0$ & $2 \pm 0$ & $5 \pm 1$ & $0 \pm 0$ \\
\hline & & Impact & $291 \pm 7$ & $394 \pm 88$ & $65 \pm 13$ & $16 \pm 0$ & $5 \pm 0$ & $6 \pm 4$ & $13 \pm 4$ & $1 \pm 1$ \\
\hline & Vegetated & Control & $723 \pm 95$ & $284 \pm 145$ & $69 \pm 42$ & $16 \pm 10$ & $3 \pm 1$ & $5 \pm 2$ & $12 \pm 8$ & $0 \pm 0$ \\
\hline & & Impact & $938 \pm 239$ & $255 \pm 39$ & $77 \pm 36$ & $21 \pm 9$ & $2 \pm 0$ & $6 \pm 1$ & $28 \pm 11$ & $0 \pm 0$ \\
\hline \multirow[t]{5}{*}{ Spain } & Non-vegetated & Control & $1467 \pm 521$ & $539 \pm 63$ & $144 \pm 32$ & $6 \pm 6$ & $3 \pm 4$ & $24 \pm 3$ & $150 \pm 131$ & $0 \pm 0$ \\
\hline & & Impact & $2342 \pm 737$ & $305 \pm 107$ & $222 \pm 108$ & $1 \pm 2$ & $1 \pm 1$ & $72 \pm 52$ & $10 \pm 12$ & $0 \pm 0$ \\
\hline & Vegetated & Control & $2084 \pm 639$ & $488 \pm 186$ & $129 \pm 65$ & $7 \pm 2$ & $2 \pm 3$ & $252 \pm 102$ & $11 \pm 10$ & $0 \pm 0$ \\
\hline & & Impact & $3381 \pm 406$ & $432 \pm 420$ & $125 \pm 60$ & $37 \pm 12$ & $4 \pm 5$ & $33 \pm 27$ & $41 \pm 47$ & $0 \pm 0$ \\
\hline & & & Kynorhyncha & Tardigrada & Cumacea & Amphipoda & Isopoda & Tanaidacea & Acarina & Nemertina \\
\hline \multirow[t]{4}{*}{ Cyprus } & Non-vegetated & Control & $11 \pm 3$ & $0 \pm 0$ & $0 \pm 0$ & $0 \pm 1$ & $0 \pm 0$ & $1 \pm 0$ & $0 \pm 0$ & $20 \pm 7$ \\
\hline & & Impact & $9 \pm 9$ & $0 \pm 0$ & $0 \pm 0$ & $0 \pm 1$ & $0 \pm 0$ & $0 \pm 0$ & $0 \pm 0$ & $5 \pm 3$ \\
\hline & Vegetated & Control & $1 \pm 0$ & $0 \pm 0$ & $1 \pm 0$ & $1 \pm 1$ & $1 \pm 0$ & $0 \pm 0$ & $0 \pm 0$ & $4 \pm 4$ \\
\hline & & Impact & $3 \pm 0$ & $2 \pm 2$ & $0 \pm 0$ & $1 \pm 1$ & $1 \pm 0$ & $2 \pm 0$ & $1 \pm 1$ & $7 \pm 7$ \\
\hline \multirow[t]{4}{*}{ Greece } & Non-vegetated & Control & $19 \pm 10$ & $9 \pm 9$ & $0 \pm 0$ & $2 \pm 1$ & $0 \pm 0$ & $1 \pm 1$ & $2 \pm 2$ & $46 \pm 34$ \\
\hline & & Impact & $22 \pm 7$ & $2 \pm 2$ & $0 \pm 0$ & $0 \pm 1$ & $0 \pm 0$ & $0 \pm 0$ & $0 \pm 0$ & $292 \pm 160$ \\
\hline & Vegetated & Control & $15 \pm 5$ & $12 \pm 9$ & $44 \pm 17$ & $0 \pm 1$ & $2 \pm 0$ & $5 \pm 3$ & $0 \pm 0$ & $0 \pm 0$ \\
\hline & & Impact & $14 \pm 5$ & $20 \pm 15$ & $2 \pm 1$ & $0 \pm 1$ & $1 \pm 0$ & $0 \pm 0$ & $4 \pm 3$ & $62 \pm 46$ \\
\hline \multirow[t]{4}{*}{ Italy } & Non-vegetated & Control & $2 \pm 2$ & $36 \pm 4$ & $0 \pm 0$ & $1 \pm 1$ & $1 \pm 0$ & $7 \pm 3$ & $7 \pm 0$ & $1 \pm 1$ \\
\hline & & Impact & $0 \pm 0$ & $0 \pm 0$ & $0 \pm 0$ & $0 \pm 1$ & $0 \pm 0$ & $0 \pm 0$ & $0 \pm 0$ & $1 \pm 0$ \\
\hline & Vegetated & Control & $7 \pm 1$ & $27 \pm 12$ & $1 \pm 1$ & $0 \pm 1$ & $1 \pm 0$ & $3 \pm 2$ & $3 \pm 2$ & $5 \pm 4$ \\
\hline & & Impact & $0 \pm 0$ & $14 \pm 8$ & $0 \pm 0$ & $0 \pm 1$ & $0 \pm 0$ & $0 \pm 0$ & $1 \pm 0$ & $5 \pm 1$ \\
\hline \multirow[t]{4}{*}{ Spain } & Non-vegetated & Control & $9 \pm 7$ & $26 \pm 19$ & $1 \pm 1$ & $2 \pm 1$ & $1 \pm 0$ & $1 \pm 0$ & $5 \pm 3$ & $4 \pm 2$ \\
\hline & & Impact & $0 \pm 0$ & $0 \pm 0$ & $0 \pm 0$ & $0 \pm 1$ & $0 \pm 0$ & $2 \pm$ & $0 \pm 0$ & $77 \pm 56$ \\
\hline & Vegetated & Control & $8 \pm 0$ & $44 \pm 26$ & $0 \pm 0$ & $2 \pm 1$ & $1 \pm 0$ & $2 \pm 0$ & $1 \pm 1$ & $4 \pm 2$ \\
\hline & & Impact & $8 \pm 0$ & $66 \pm 57$ & $0 \pm 0$ & $1 \pm 1$ & $0 \pm 0$ & $2 \pm 0$ & $3 \pm 3$ & $30 \pm 23$ \\
\hline
\end{tabular}


24 Table 5 - Results of ANOVA testing for differences between impact and control sites in abundance of the meiofaunal taxa in different habitats and regions. $\mathrm{R}=$ region; $\mathrm{H}=$ habitat; $\mathrm{I}=$ impact; $\mathrm{SS}=$ sum of squares; $\mathrm{DF}=$ degrees of freedom; $\mathrm{MS}=$ means square; $\mathrm{F}=\mathrm{F}$ value; $\mathrm{P}=$ probability level: $* * *=\mathrm{P}<0.001 ; * *=\mathrm{P}<0.01 ; *=\mathrm{P}<0.05 ; \mathrm{ns}=$ not significant.

\begin{tabular}{|c|c|c|c|c|c|c|}
\hline \multirow{10}{*}{ Nematodes } & Source & SS & DF & MS & $\mathbf{F}$ & $\mathbf{P}$ \\
\hline & $\mathbf{R}$ & 13.15 & 3 & 4.38 & 38.98 & $* * *$ \\
\hline & $\mathbf{H}$ & 0.06 & 1 & 0.06 & 0.04 & $\mathrm{~ns}$ \\
\hline & $\mathbf{I}$ & 2.66 & 1 & 2.66 & 4.47 & ns \\
\hline & $\mathbf{R} \times \mathbf{H}$ & 4.34 & 3 & 1.45 & 12.86 & $* * *$ \\
\hline & $\mathbf{R} \times \mathbf{I}$ & 1.78 & 3 & 0.59 & 5.29 & $* *$ \\
\hline & $\mathbf{H} \times \mathbf{I}$ & 0.10 & 1 & 0.10 & 0.36 & ns \\
\hline & $\mathbf{R} \times \mathbf{H} \times \mathbf{I}$ & 0.82 & 3 & 0.27 & 2.42 & ns \\
\hline & Residuals & 3.60 & 32 & 0.11 & & \\
\hline & Total & 26.50 & 47 & & & \\
\hline \multirow[t]{9}{*}{ Copepods } & $\mathbf{R}$ & 1116932.28 & 3 & 372310.76 & 6.23 & $* *$ \\
\hline & $\mathbf{H}$ & 17542.98 & 1 & 17542.98 & 1.01 & ns \\
\hline & $\mathbf{I}$ & 30403.35 & 1 & 30403.35 & 0.38 & ns \\
\hline & $\mathbf{R} \times \mathbf{H}$ & 52331.00 & 3 & 17443.67 & 0.29 & ns \\
\hline & $\mathbf{R} \times \mathbf{I}$ & 237589.60 & 3 & 79196.53 & 1.33 & ns \\
\hline & $\mathbf{H} \times \mathbf{I}$ & 1332.47 & 1 & 1332.47 & 0.11 & sn \\
\hline & $\mathbf{R} \times \mathbf{H} \times \mathbf{I}$ & 35031.09 & 3 & 11677.03 & 0.20 & sn \\
\hline & Residuals & 1912625.14 & 32 & 59769.54 & & \\
\hline & Total & 3403787.91 & 47 & & & \\
\hline \multirow[t]{9}{*}{ Polychaetes } & $\mathbf{R}$ & 170.08 & 3 & 56.69 & 8.01 & $* * *$ \\
\hline & $\mathbf{H}$ & 39.79 & 1 & 39.79 & 1.39 & $\mathrm{~ns}$ \\
\hline & $\mathbf{I}$ & 96.90 & & 96.90 & 2.63 & ns \\
\hline & $\mathbf{R} \times \mathbf{H}$ & 85.71 & 3 & 28.57 & 4.04 & $*$ \\
\hline & $\mathbf{R} \times \mathbf{I}$ & 110.65 & 3 & 36.88 & 5.21 & $* *$ \\
\hline & $\mathbf{H} \times \mathbf{I}$ & 66.82 & 1 & 66.82 & 1.12 & ns \\
\hline & $\mathbf{R} \times \mathbf{H} \times \mathbf{I}$ & 179.26 & 3 & 59.75 & 8.44 & $* * *$ \\
\hline & Residuals & 226.52 & 32 & 7.08 & & \\
\hline & Total & 975.73 & 47 & & & \\
\hline \multirow[t]{9}{*}{ Ostracods } & $\mathbf{R}$ & 24.69 & 3 & 8.23 & 16.96 & $* * *$ \\
\hline & $\mathbf{H}$ & 1.53 & 1 & 1.53 & 0.60 & ns \\
\hline & $\mathbf{I}$ & 0.01 & 1 & 0.01 & 0.04 & ns \\
\hline & $\mathbf{R} \times \mathbf{H}$ & 7.58 & 3 & 2.53 & 5.21 & $* *$ \\
\hline & $\mathbf{R} \times \mathbf{I}$ & 0.40 & 3 & 0.13 & 0.28 & ns \\
\hline & $\mathbf{H} \times \mathbf{I}$ & 1.75 & 1 & 1.75 & 1.39 & ns \\
\hline & $\mathbf{R} \times \mathbf{H} \times \mathbf{I}$ & 3.77 & 3 & 1.26 & 2.59 & ns \\
\hline & Residuals & 15.53 & 32 & 0.49 & & \\
\hline & Total & 55.26 & 47 & & & \\
\hline
\end{tabular}

\begin{tabular}{|c|c|c|c|c|c|}
\hline \multirow{10}{*}{ Turbellarians } & Source & SS & DF & MS & $\mathbf{F}$ \\
\hline & $\mathbf{R}$ & 18.88 & 3 & 6.29 & $12.8 \mathrm{r}$ \\
\hline & H & 2.28 & 1 & 2.28 & $3.6 !$ \\
\hline & I & 0.41 & 1 & 0.41 & 1.9 \\
\hline & $\mathbf{R} \times \mathbf{H}$ & 1.86 & 3 & 0.62 & 1.21 \\
\hline & $\mathbf{R} \times \mathbf{I}$ & 0.65 & 3 & 0.22 & 0.4 \\
\hline & $\mathbf{H} \times \mathbf{I}$ & 0.03 & 1 & 0.03 & 0.0 \\
\hline & $\mathbf{R} \times \mathbf{H} \times \mathbf{I}$ & 1.96 & 3 & 0.65 & 1.3. \\
\hline & Residuals & 15.66 & 32 & 0.49 & \\
\hline & Total & 41.73 & 47 & & \\
\hline \multirow[t]{9}{*}{ Oligochaetes } & $\mathbf{R}$ & 59266.22 & 3 & 19755.41 & 1.8 \\
\hline & $\mathbf{H}$ & 56.14 & 1 & 56.14 & 0.01 \\
\hline & I & 223.39 & 1 & 223.39 & $0.0^{\prime}$ \\
\hline & $\mathbf{R} \times \mathbf{H}$ & 40553.05 & 3 & 13517.68 & 1.2 \\
\hline & $\mathbf{R} \times \mathbf{I}$ & 41567.71 & 3 & 13855.90 & $1.2^{\prime}$ \\
\hline & $\mathbf{H} \times \mathbf{I}$ & 34558.65 & 1 & 34558.65 & 3.41 \\
\hline & $\mathbf{R} \times \mathbf{H} \times \mathbf{I}$ & 29968.09 & 3 & 9989.36 & 0.9 \\
\hline & Residuals & 349658.16 & 32 & 10926.82 & \\
\hline & Total & 555851.41 & 47 & & \\
\hline \multirow[t]{9}{*}{ Gastrotrichs } & $\mathbf{R}$ & 49.57 & 3 & 16.52 & $19.5 i$ \\
\hline & $\mathbf{H}$ & 0.66 & 1 & 0.66 & 0.5 \\
\hline & I & 5.48 & 1 & 5.48 & $1.8^{\prime}$ \\
\hline & $\mathbf{R} \times \mathbf{H}$ & 3.67 & 3 & 1.22 & 1.4: \\
\hline & $\mathbf{R} \times \mathbf{I}$ & 9.05 & 3 & 3.02 & $3.5^{\prime}$ \\
\hline & $\mathbf{H} \times \mathbf{I}$ & 1.80 & 1 & 1.80 & 0.4 \\
\hline & $\mathbf{R} \times \mathbf{H} \times \mathbf{I}$ & 12.30 & 3 & 4.10 & 4.81 \\
\hline & Residuals & 27.00 & 32 & 0.84 & \\
\hline & Total & 109.54 & 47 & & \\
\hline \multirow[t]{9}{*}{ Nemertins } & $\mathbf{R}$ & 33.06 & 3 & 11.02 & 23.51 \\
\hline & $\mathbf{H}$ & 5.29 & 1 & 5.29 & $0.8^{\prime}$ \\
\hline & I & 14.88 & 1 & 14.88 & 2.01 \\
\hline & $\mathbf{R} \times \mathbf{H}$ & 19.28 & 3 & 6.43 & 13.7 \\
\hline & $\mathbf{R} \times \mathbf{I}$ & 22.38 & 3 & 7.46 & 15.9 \\
\hline & $\mathbf{H} \times \mathbf{I}$ & 1.25 & 1 & 1.25 & 0.91 \\
\hline & $\mathbf{R} \times \mathbf{H} \times \mathbf{I}$ & 4.16 & 3 & 1.39 & 2.91 \\
\hline & Residuals & 15.00 & 32 & 0.47 & \\
\hline & Total & 115.29 & 47 & & \\
\hline
\end{tabular}




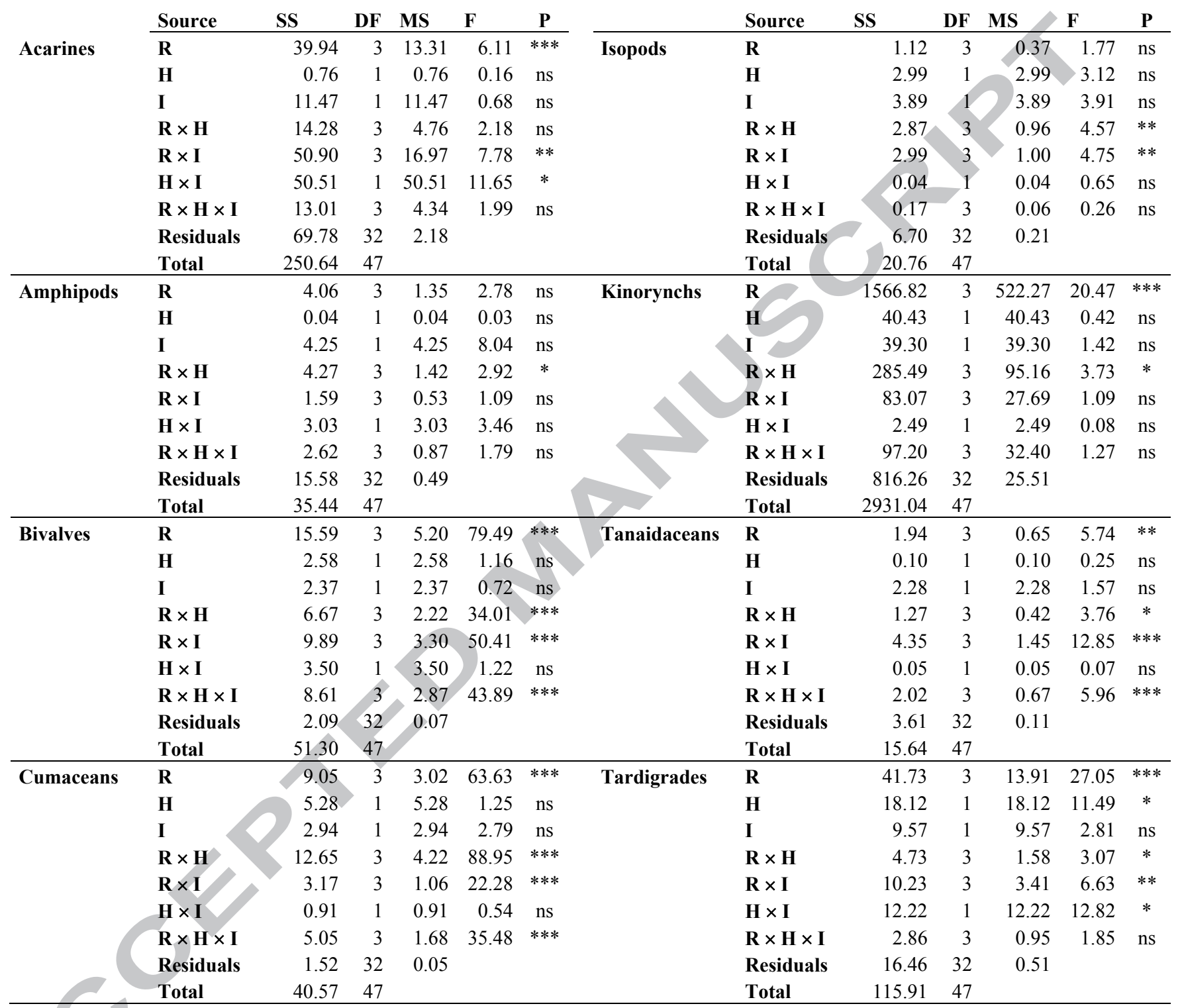


31 Table 6 - Results of PERMANOVA testing for differences in the whole set of meiofaunal taxa.

The analysis was done on the distance matrix calculated using Bray-Curtis similarities on untransformed data. Each term was tested using 4,999 random permutations of the appropriate units $(* * *=\mathrm{P}<0.001 ; * *=\mathrm{P}<0.01 ; *=\mathrm{P}<0.05$; ns $=$ not significant). $\mathrm{DF}=$ degrees of freedom, $\mathrm{MS}=$ mean square, $\mathrm{F}=\mathrm{F}$-value; $\mathrm{P}(\mathrm{MC})=$ Monte Carlo probability level. Reported are also the results of the pairwise comparisons testing differences between impact and control sites

\section{PERMANOVA outputs}

\begin{tabular}{lllll} 
& $\mathbf{D F}$ & $\mathbf{M S}$ & $\mathbf{F}$ & $\mathbf{P}(\mathbf{M C})$ \\
\hline $\mathbf{R}$ & 3 & 5835.49 & 19.49 & $* * *$ \\
$\mathbf{H}$ & 1 & 1111.62 & 0.76 & $\mathrm{~ns}$ \\
$\mathbf{I}$ & 1 & 3614.80 & 3.56 & $\mathrm{~ns}$ \\
$\mathbf{R} \times \mathbf{H}$ & 3 & 1455.63 & 4.86 & $* *$ \\
$\mathbf{R} \times \mathbf{I}$ & 3 & 1016.26 & 3.39 & $* *$ \\
$\mathbf{H} \times \mathbf{I}$ & 1 & 418.29 & 0.51 & $\mathrm{~ns}$ \\
$\mathbf{R} \times \mathbf{H} \times \mathbf{I}$ & 3 & 818.36 & 2.73 & $* *$ \\
$\mathbf{R e s i d u a l s}$ & 32 & 299.37 & & \\
Total & 47 & & & \\
\hline
\end{tabular}

40

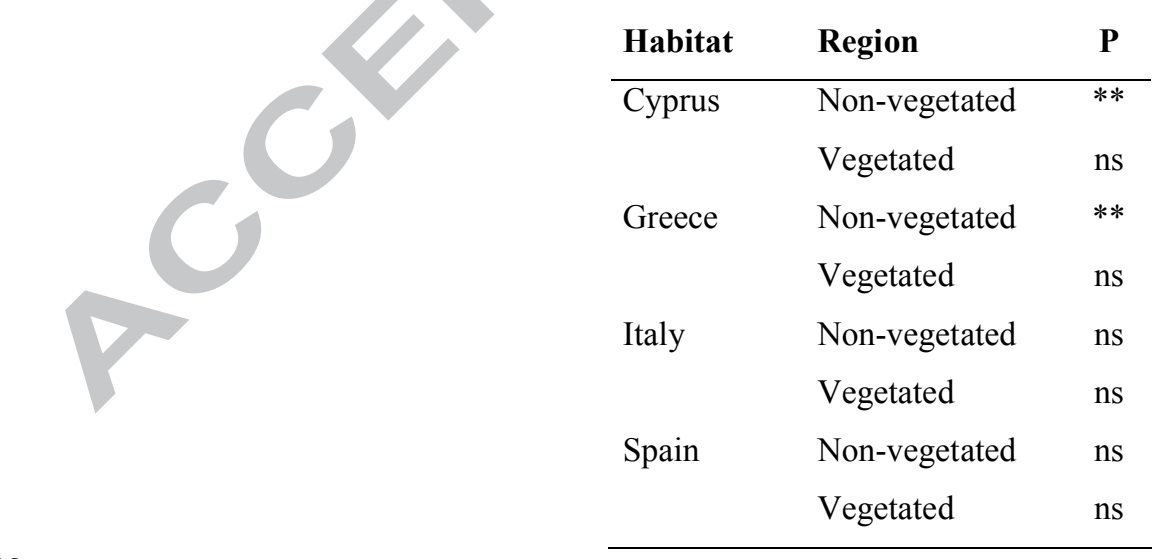


45 Table 7 - Results of ANOVA testing for differences between impact and control sites in richness

46 and evenness of meiofaunal taxa in different habitats and regions. $\mathrm{R}=$ region; $\mathrm{H}=$ habitat; $\mathrm{I}=$

47 impact; $\mathrm{SS}=$ sum of squares; $\mathrm{DF}=$ degrees of freedom; $\mathrm{MS}=$ means square; $\mathrm{F}=\mathrm{F}$ value; $\mathrm{P}=$

48 probability level: $* * *=\mathrm{P}<0.001 ; \mathrm{ns}=$ not significant.

49

\begin{tabular}{llccccc} 
& Source & SS & DF & MS & F & P \\
\hline Number of taxa & $\mathbf{R}$ & 47.5 & 3 & 15.8 & 126.67 & $* * *$ \\
& $\mathbf{H}$ & 24.1 & 1 & 24.1 & 9.32 & $\mathrm{~ns}$ \\
& $\mathbf{I}$ & 48.0 & 1 & 48.0 & 32.00 & $*$ \\
& $\mathbf{R} \times \mathbf{H}$ & 7.8 & 3 & 2.6 & 20.67 & $* * *$ \\
& $\mathbf{R} \times \mathbf{I}$ & 4.5 & 3 & 1.5 & 12.00 & $* * *$ \\
& $\mathbf{H} \times \mathbf{I}$ & 30.1 & 1 & 30.1 & 15.70 & $*$ \\
& $\mathbf{R} \times \mathbf{H} \times \mathbf{I}$ & 5.8 & 3 & 1.9 & 15.33 & $* * *$ \\
& Residuals & 4 & 32 & 0.1 & & \\
& Total & 171.7 & 47 & & & \\
\hline Community Evenness & $\mathbf{R}$ & 0.327 & 3 & 0.109 & 27.31 & $* * *$ \\
& $\mathbf{H}$ & 0.018 & 1 & 0.018 & 8.59 & $\mathrm{~ns}$ \\
& $\mathbf{I}$ & 0.003 & 1 & 0.003 & 0.53 & $\mathrm{~ns}$ \\
& $\mathbf{R} \times \mathbf{H}$ & 0.006 & 3 & 0.002 & 0.53 & $\mathrm{~ns}$ \\
& $\mathbf{R} \times \mathbf{I}$ & 0.015 & 3 & 0.005 & 1.28 & $\mathrm{~ns}$ \\
& $\mathbf{H} \times \mathbf{I}$ & 0.027 & 1 & 0.028 & 4.48 & $\mathrm{~ns}$ \\
& $\mathbf{R} \times \mathbf{H} \times \mathbf{I}$ & 0.018 & 3 & 0.006 & 1.54 & $\mathrm{~ns}$ \\
& Residuals & 0.128 & 32 & 0.004 & & \\
& Total & 0.543 & 47 & & & \\
\hline
\end{tabular}

50

51 
52 Table 8 - Results of PERMANOVA testing for differences between impact and control sites in 53 total meiofaunal abundance in different habitats and regions, after the removal of the covariate

54 effects. $\mathrm{R}=$ region; $\mathrm{H}=$ habitat; $\mathrm{I}=$ impact; $\mathrm{SS}=$ sum of squares; $\mathrm{DF}=$ degrees of freedom; $\mathrm{MS}$

55 = means square; $\mathrm{F}=\mathrm{F}$ value; $\mathrm{P}=$ probability level: $* * *=\mathrm{P}<0.001$; $\mathrm{ns}=$ not significant.

56 Covariates included: biopolymeric $\mathrm{C}$ contents, protein to carbohydrate values, water depth,

57 sediment porosity and water content and current.

58

59

$\begin{array}{lccccc}\text { Source } & \text { DF } & \text { SS } & \text { MS } & \text { F } & \text { P } \\ \text { Covariables } & 6 & 7.395 & 1.232 & 7.45 & * * \\ \mathbf{R} & 3 & 0.406 & 0.135 & 1.28 & \mathrm{~ns} \\ \mathbf{H} & 1 & 0.082 & 0.081 & 0.09 & \mathrm{~ns} \\ \mathbf{I} & 1 & 1.128 & 1.127 & -0.78 & \mathrm{~ns} \\ \mathbf{R} \times \mathbf{H} & 3 & 489.232 & 163.077 & -38.78 & \mathrm{~ns} \\ \mathbf{R} \times \mathbf{I} & 3 & -12.148 & -4.049 & 2.22 & \mathrm{~ns} \\ \mathbf{H} \times \mathbf{I} & 1 & 1.851 & 1.851 & -0.35 & \mathrm{~ns} \\ \mathbf{R} \times \mathbf{H} \times \mathbf{I} & 3 & 0.609 & 0.203 & 0.61 & \mathrm{~ns} \\ \mathbf{R} \text { esidual } & 26 & 8.521 & 0.327 & & \\ \text { Total } & 47 & 13.398 & & & \end{array}$

60 
61 Table 9 - Results of the multiple regression analysis of meiofaunal abundance (square root

62 transformed), taxa richness (untransformed) and community evenness over the environmental

63 variables. Prop $=$ proportional; $\mathrm{Cu}$, = cumulative.

64

\begin{tabular}{|c|c|c|c|c|c|}
\hline & Variable & pseudo-F & $\mathbf{P}$ & $\begin{array}{l}\text { Expla } \\
\text { Prop }\end{array}$ & $\begin{array}{l}\text { variance } \\
\text { Cum }\end{array}$ \\
\hline \multirow[t]{6}{*}{$\begin{array}{l}\text { Meiofaunal } \\
\text { abundance }\end{array}$} & Current & 8.17 & 0.012 & 15.08 & 15.08 \\
\hline & Biopolymeric C & 5.13 & 0.032 & 8.7 & 23.77 \\
\hline & Protein to carbohydrate ratio & 2.64 & ns & 4.31 & 28.09 \\
\hline & Water depth & 0.13 & ns & 0.21 & 28.30 \\
\hline & Sediment porosity & 0.07 & ns & 0.11 & 28.41 \\
\hline & Sediment water content & 0.01 & ns & 0.01 & 28.42 \\
\hline \multirow[t]{6}{*}{ Taxa richness } & Water depth & 11.19 & 0.004 & 19.56 & 19.56 \\
\hline & Current & 9.07 & 0.014 & 13.49 & 33.05 \\
\hline & Protein to carbohydrate ratio & 12.81 & 0.002 & 15.09 & 48.14 \\
\hline & Sediment porosity & 0.58 & ns & 0.69 & 48.84 \\
\hline & Biopolymeric C & 0.30 & ns & 0.36 & 49.20 \\
\hline & Sediment water content & 0.87 & ns & 1.05 & 50.25 \\
\hline \multirow[t]{6}{*}{$\begin{array}{l}\text { Community } \\
\text { evenness }\end{array}$} & Current & 19.71 & 0.002 & 29.99 & 29.99 \\
\hline & Water depth & 14.85 & 0.002 & 17.37 & 47.37 \\
\hline & Biopolymeric C & 1.15 & ns & 1.34 & 48.71 \\
\hline & Sediment porosity & 0.90 & ns & 1.06 & 49.76 \\
\hline & Protein to carbohydrate ratio & 0.85 & ns & 0.99 & 50.76 \\
\hline & Sediment water content & 0.07 & ns & 0.09 & 50.84 \\
\hline
\end{tabular}

65

66

67 
Western Mediterranean

Spain (Alicante)
Eastern Mediterranean

Greece (Sounio)

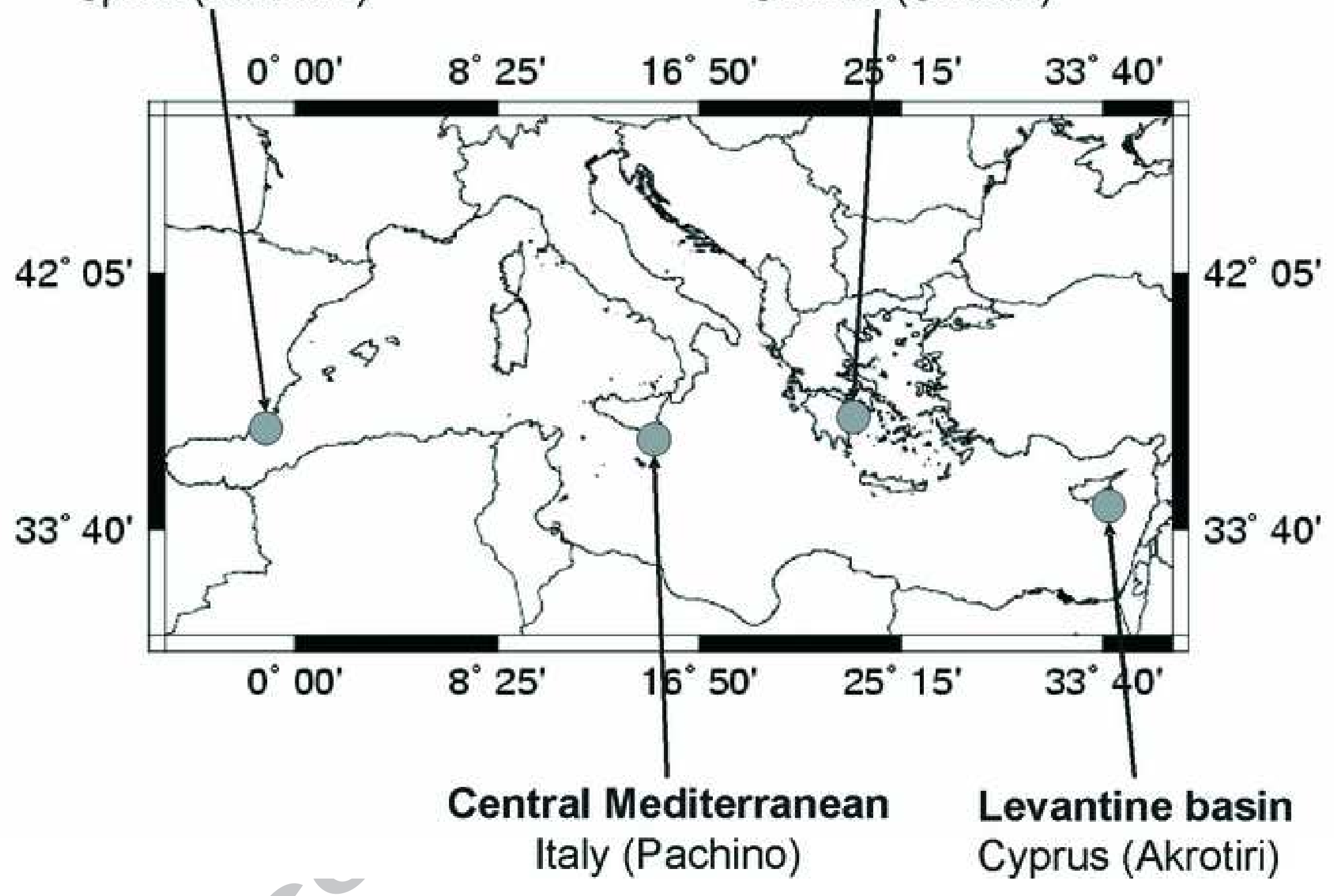



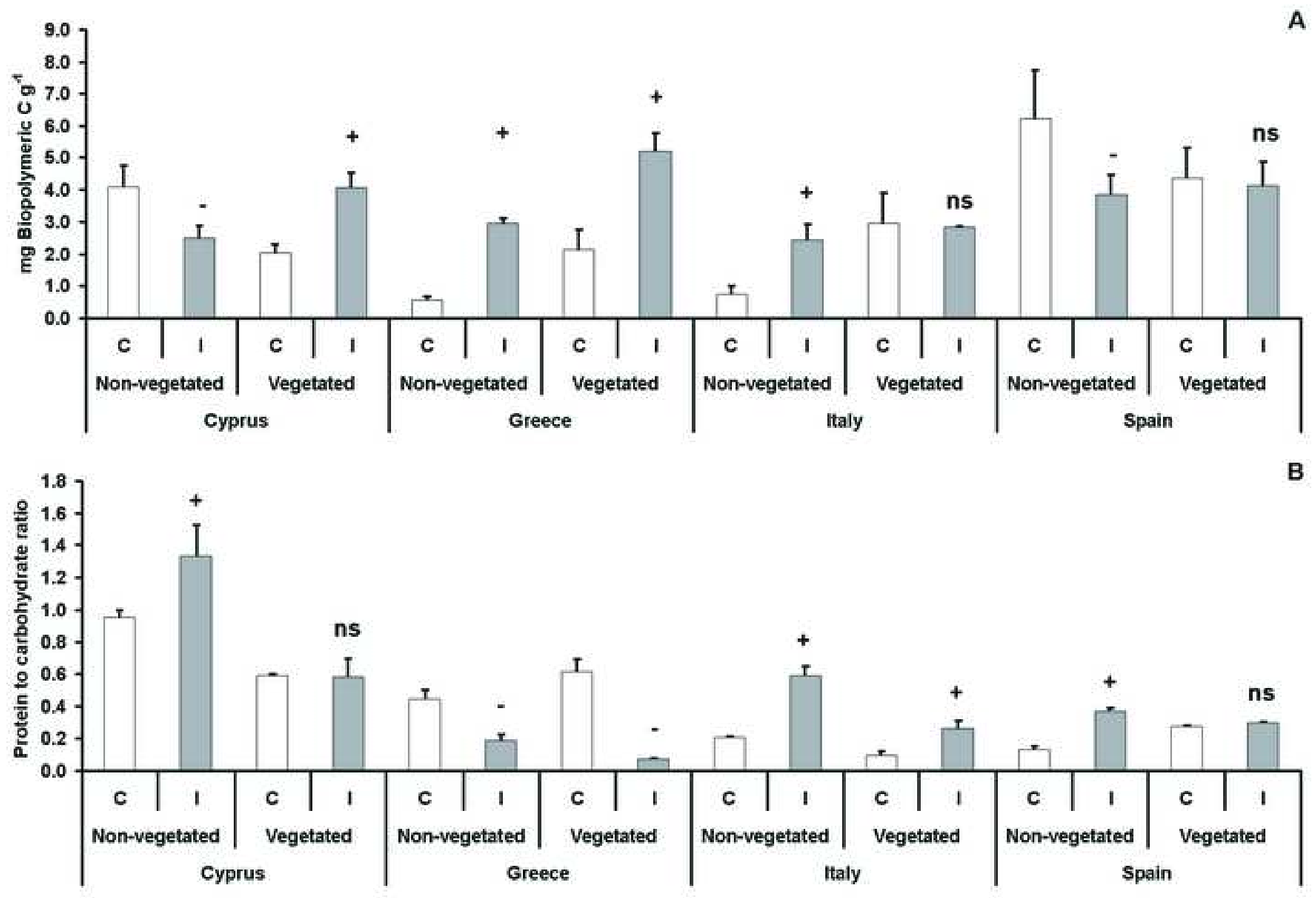

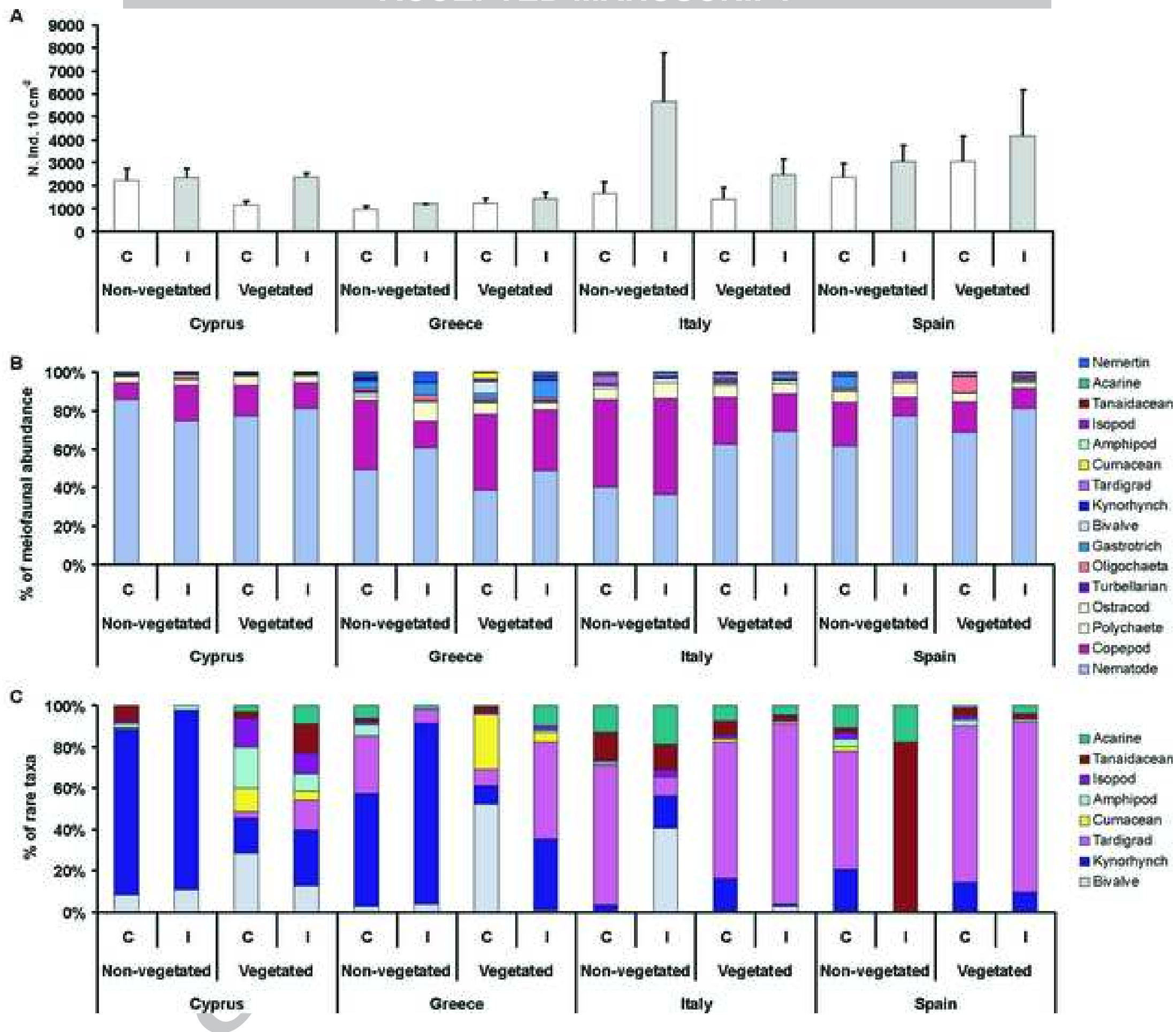

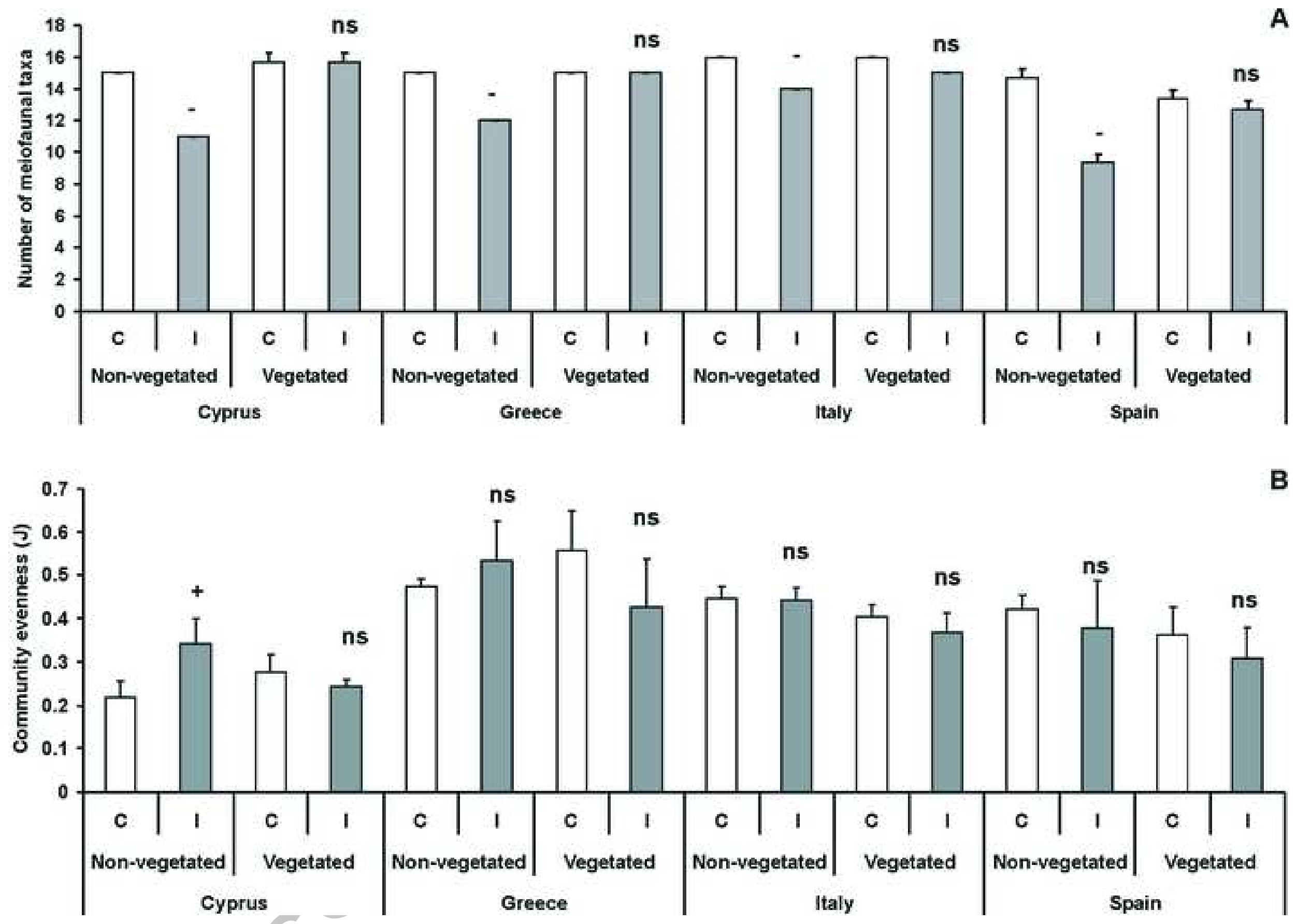